地すべり 第28巻 第 1 号

Journal of Japan Landslide Society 28-1(1991)

\title{
地山応力に対する間隙水圧の影響 \\ The Influence of Pore Water Pressure on the Stress in a Soil Mass
}

\author{
山田壽 政 ${ }^{*}$ 小島 義 孝** 速 水 博 秀 ${ }^{* * *}$ \\ Toshimasa YAMAdA Yoshitaka KoJIMA Hirohide HAYAMIZU
}

\begin{abstract}
This paper emphasizes that the influence of pore water pressure should be kaken into account when we analyze the stress in a soil mass or evaluate the stability of a slope. Although the stress in a soil mass varies with pore water pressures, most of the available FEM computer programs leave it out of consideration.

We propose an improved computer program which includes the parameter of pore water pressure based on the Biot's theory. To understand the relationship between the stress and pore water pressure, we discussed two simple cases. In the first case, we concluded that the effect of pore water pressure should be taken into accout in designing a retaining wall.

In the sccond case, we calculated the stress in a slope of a dam model, of which pore water pressures varied with water levesls of the reservoir. The results show that the factor of safety calculated tends to be smaller when the effect of pore water pressure was taken into account.
\end{abstract}

キーワード：地山応力, 間隙水圧, 応力解析, 安定性評価, 擁壁設計

\section{1.はしがき}

傾斜地形の安定性評価は災害防止上の重要事項なので 多くの評価法が開発され, さらに新規評価法も提案され ている。それらの一つとして最近有限要素法による応力 解析の実施例を見受けるようになった。ただ有限要素法 による評洒では一般に全体安全率に対する判断が十分で なくこれが欠点と考えられるが, 各部に発生する応力, ひずみ，変位を精密に知ることが可能なことに利点があ ると言われている。

なおこのような安定性の評価では, 地山中の間隙水圧 の影響を正確に考慮する必要があることは言うまでもな い。すなわち安定性評価に対する間隙水圧の影響として まず第一に滑り発生限界に関するものがあるが, さらに 間吵水压による応力そのものの変化がある。これらのう ち前者についてはモール・クーロンのせん断破壊規準を 改良した

$$
f=\frac{c+(\sigma-p) \tan \phi}{\tau}
$$

が使用されており, 間吵水压が考慮されていることは良 く知られている。ただし $f$ は安全率, $c$ は粘着力, $\phi$ はせん 断抵抗角， $\sigma ， \tau$ はそれぞれ滑り面に作用する真の圧縮応 力, せん断応力, p澗隙水圧である。

* 日本基礎技術(侏)技術本部技術システム部

* 日本基礎技術(侏技術本部調査設計第一部

*氺水日本基礎技術(侏技術本部顧問
一方後者すなわち上式に示した応力 $\sigma, \tau$ 自身に対する 間隙水圧の影響については無視するか近似的に考慮する のみで正確な考慮は行われていなかったように思われる。 従来ビオらにより間隙水圧と応力の関係について多くの 理論的研究結果が発表されているにもかかわらず，この 結果が安定評価に取り入れられなかった理由として地山 に発生するひずみを考慮しない評価法が一般に行われて いたためと考えられる。すなわちビオの論文 ${ }^{1)}$ によれば, 応力解析に於いて間隙水圧は対象物体の応力・ひずみ関 係式に影響するので, ひずみを考慮している有限要素応 力解析法ならば上記理論を取り入れることが可能である。

しかし現在市販されている普通の有限要素応力解析プ ログラムには間隙水庄の影響を考慮する機能はないよう である。そこで我々は市販プログラムの改造を行い間吵 水圧を考慮できるようにした。また従来から手持ちの有 限要素浸透流解析プログラムとこのプログラムを結合し， 地層中に浸透流が存在する場合についてその圧力を考慮 して応力解析できるようにした。

\section{2. 間隙水圧を考慮した有限要素応力解析プロ グラム}

有限要素法によって応力解析を行うとき，必要とされ る関係式は次の通りである。まず節点変位べクトル $\{u\}$ とひずみべクトル $\{\varepsilon\} の$ 関係として, 間吵水圧の有無によ らず

$\{\varepsilon\}=[B]\{u\}$ (1) 
が必要である。ただし， $[B]$ は形状関数マトリックス $[N]$ の要素を座標 $x$, 座標 $y て ゙$ 微分した関数によって構成され た形状関数の微分マトリックスである。

応力ベクトル $\{\sigma\}$ は引つ張り応力を正值とし, 間隙水圧 の影響を考慮すると

$$
\{\sigma\}=[D]\{\varepsilon\}-[N N]\{P\}
$$

となる。ただし $[D]$ は弾性係数マトリックス，[NN]は要 素内の間隙水圧を定める形状関数マトリックス，\{P\}は 節点間隙水圧ベクトルである。

要素内の間隙水圧ベクトル $\{p\}=[N N]\{P\}$ を用いると (2)式は

$$
\{\sigma\}=[D]\{\varepsilon\}-\{p\}
$$

となる。間隙水圧を考慮したとき応力・ひずみ関係式が 上記の様になる理由についてはビオの論文に示されてい るが，付録に簡単な説明を示した。

有限要素法で節点変位を決定する方程式は, 応力の釣 合い方程式から求まり，地山単位体積の重量ベクトルを $\{w\}$ ，節点に作用する外力のベクトルを $\{F\}$ とすると

$$
\begin{aligned}
& \sum \int_{k}\{\delta\}^{T}[B]^{T}\{\sigma\} d s \\
& =\sum\{\delta\}^{T}\{F\}+\sum \int_{k}\{\delta\}^{T}(N]^{T}\{w\} d s
\end{aligned}
$$

となる。すなわち形式的には間隙水圧が存在しない場合 と同一になる。ただしり要素すべてにわたる和を意味 し，左辺抢よび右辺第 2 項の積分は要素 $k$ に於いて実施 するものとする。 $\{\delta\}$ は節点仮想変位べクトルである。

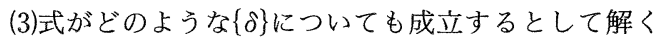
と節点変位を定めることができる。

点安全率 $S . F$ 算定式についても間隙水圧を考慮す ると，モール・クーロンのせん断破壊規準から，

$$
\text { S. } F=\frac{2 C \cos \phi+2\left(\sigma_{3}-p_{0}\right) \sin \phi}{(1-\sin \phi)\left(\sigma_{1}-\sigma_{3}\right)}
$$

または

$$
\text { S. } F=\frac{2 C \cos \phi+\left(\sigma_{1}+\sigma_{3}-2 p_{0}\right) \sin \phi}{\left(\sigma_{1}-\sigma_{3}\right)}
$$

となる ${ }^{3)}$ 。ただし $p_{0}$ は要素内平均間隚水圧， $C$ は粘着力, $\phi$ はせん断抵抗角, $\sigma_{1}, \sigma_{3}$ は圧縮を正值として求めた最大 および最小主応力である。

以上(1)式〜 (5)式を満たすよう市販の有限要素応力解析 プログラム（富士通エフ, アイ, ピーの地盤変形解析プ ログラム) を改良した。

\section{3 . 解析例 (1) 擁壁設計のための応力解析}

電子計算機による解析結果はすべて数值で与えられる が，間隙水圧が地山応力にどの様に影響するかを総合的 に見ることが困難である。このため図一 1 に示すモデル について直接理論式による解析を行った。このモデルて ヤング率 $E$, ポアソン比レを一定と仮定し, 平面ひずみ状 態を考えるとX方向の変位Uxのみが発生し，しかも座標

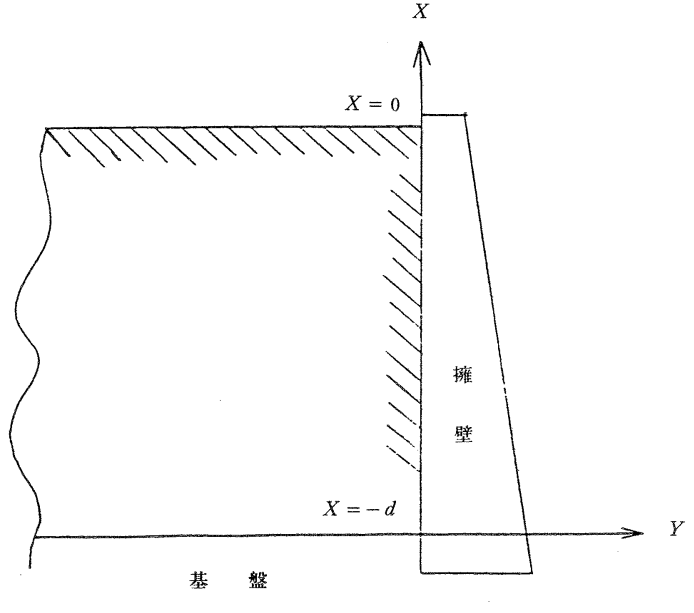

図一1 擁壁にかかる土圧解析モデル

Y，Zには無関係となる。このためひずみはX方向の縦 ひずみ

$$
\varepsilon x=\partial u x / \partial x
$$

ので，他はすべて零となる。したがって応力は $\left(2^{\prime}\right)$ 式に よって

$$
\left.\begin{array}{l}
\sigma_{x}=\frac{E(1-\nu)}{(1+\nu)(1-2 \nu)} \varepsilon_{x}-p \\
\sigma_{y}=\sigma_{z}=\frac{E \nu}{(1+\nu)(1-2 \nu)} \varepsilon_{x}-p
\end{array}\right\}
$$

となる。

応力の釣合い方程式はX方向に対するものだけ考えれ ば十分なので

$$
\frac{\partial \sigma_{x}}{\partial x}-w=0
$$

となる。ただし $w$ は土の単位体積重量である。

(8)式に(7)式の第 1 式を代入して積分し，境界条件

$$
x=0 \text { に於いて } \sigma_{x}=0
$$

を考慮すると

$$
\varepsilon_{x}=\frac{(1+\nu)(1-2 \nu)}{E(1-\nu)}(p+w x)
$$

が求まる。これを(7)式に代入して

$$
\begin{aligned}
& \sigma_{x}=w x \\
& \sigma_{y}=\sigma_{z}=\frac{\nu}{1-\nu} w x-\frac{1-2 \nu}{1-\nu} p
\end{aligned}
$$

を得る。ただしxは負値なので応力はすべて圧縮応力と なる。

(11)式の応力は以上の解析手順から明らかなようにいわ ゆる真の応力であり，この結果は真の応力自身に間隙水 圧が影響することを示している。

なお間隙氷圧を無視して応力解析を実施すると， $\sigma_{x}$ は 上記と一致するが 


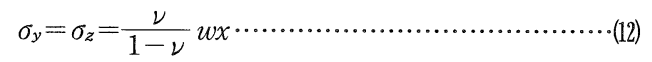

となる。(11)，(12)式から明らかなようにポアソン比 $\nu=0.5$ の場合を除いて圧縮応力 $\sigma_{y}, \sigma_{z}$ は間隙水圧により増大す ることを示している。

したがって図ー 1 の擁壁を設計する際, 間隙水圧を無 視して求めた応力 $\sigma_{y}$ を用いると強度不足となる危険性が ある。

Y (M)

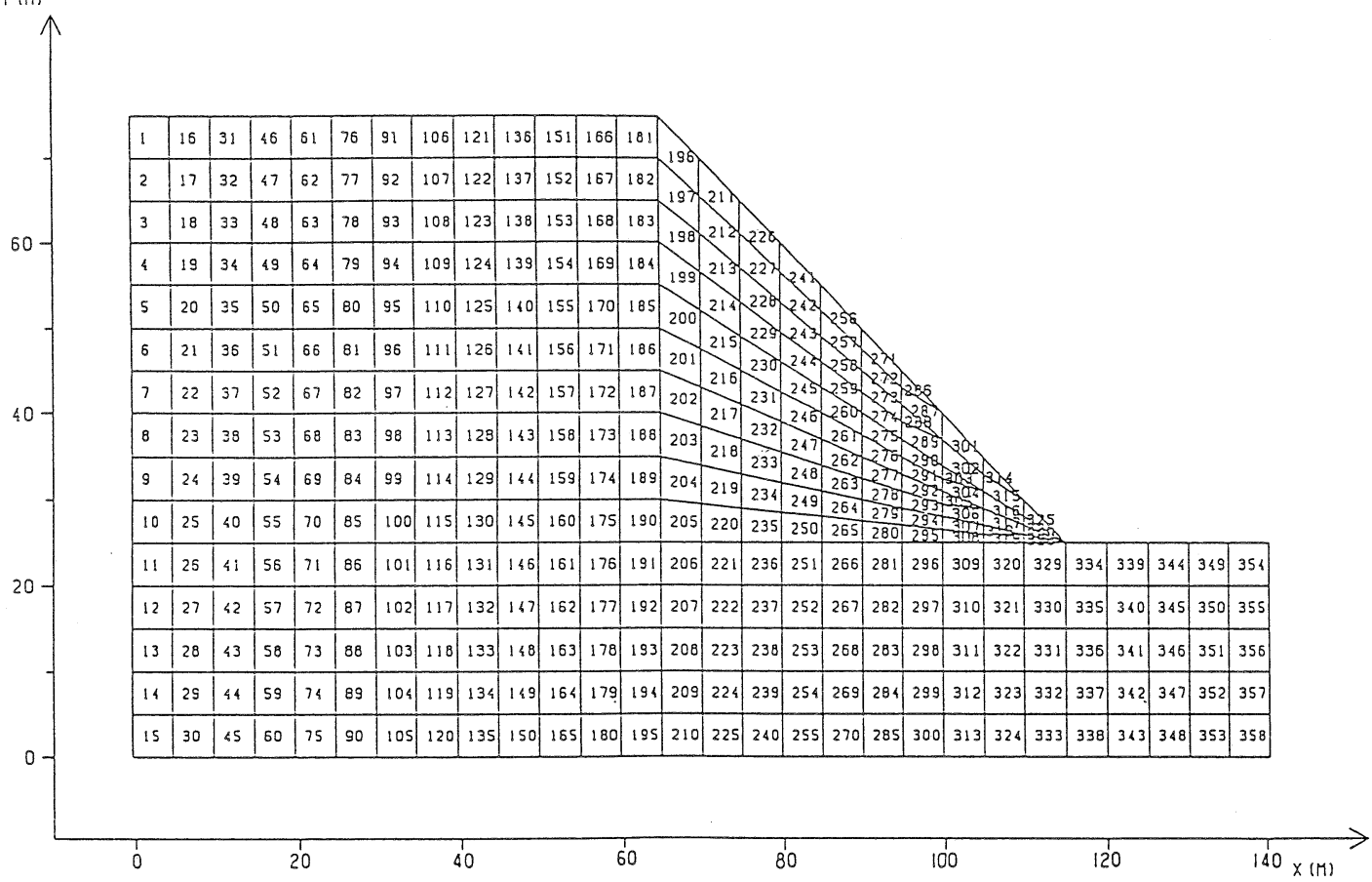

図ー2 安定性解析モデル図

\section{4. 解析例 (2) 傾斜地形の安定評価}

改造した有限要素応力解析プログラムにより間隙水圧 が地山応力に及ぼす影響を検討するため, ダム式貯水池 両岸の応力分布を解析した。解析モデルの断面を図-2 とし，水位が変化した場合について間隙水圧を非定常解 析し，この結果を用いて応力を求めた。また間隙水圧を 全く考慮しない場合の解析を行い, 点安全率を前者と比 較した。 

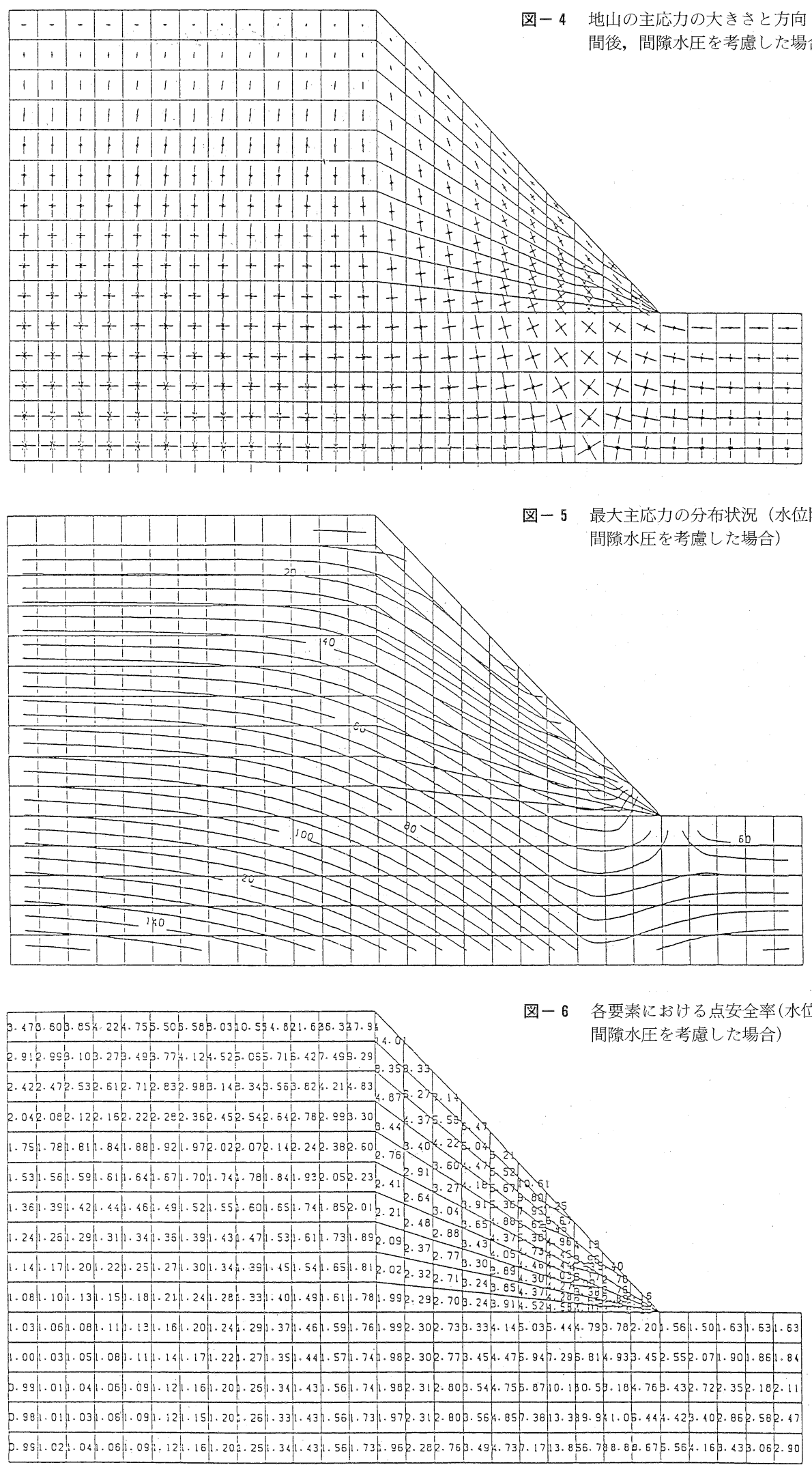


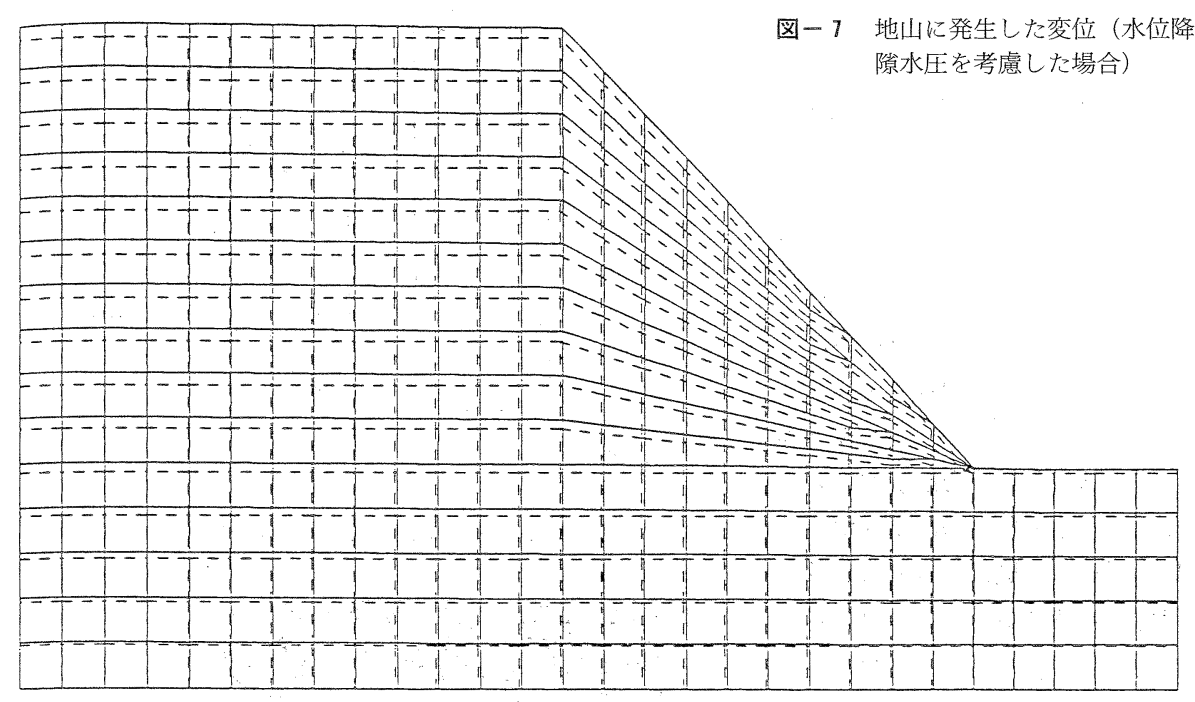

閒隙水圧考虑

間 㭞 水 圧 無 視
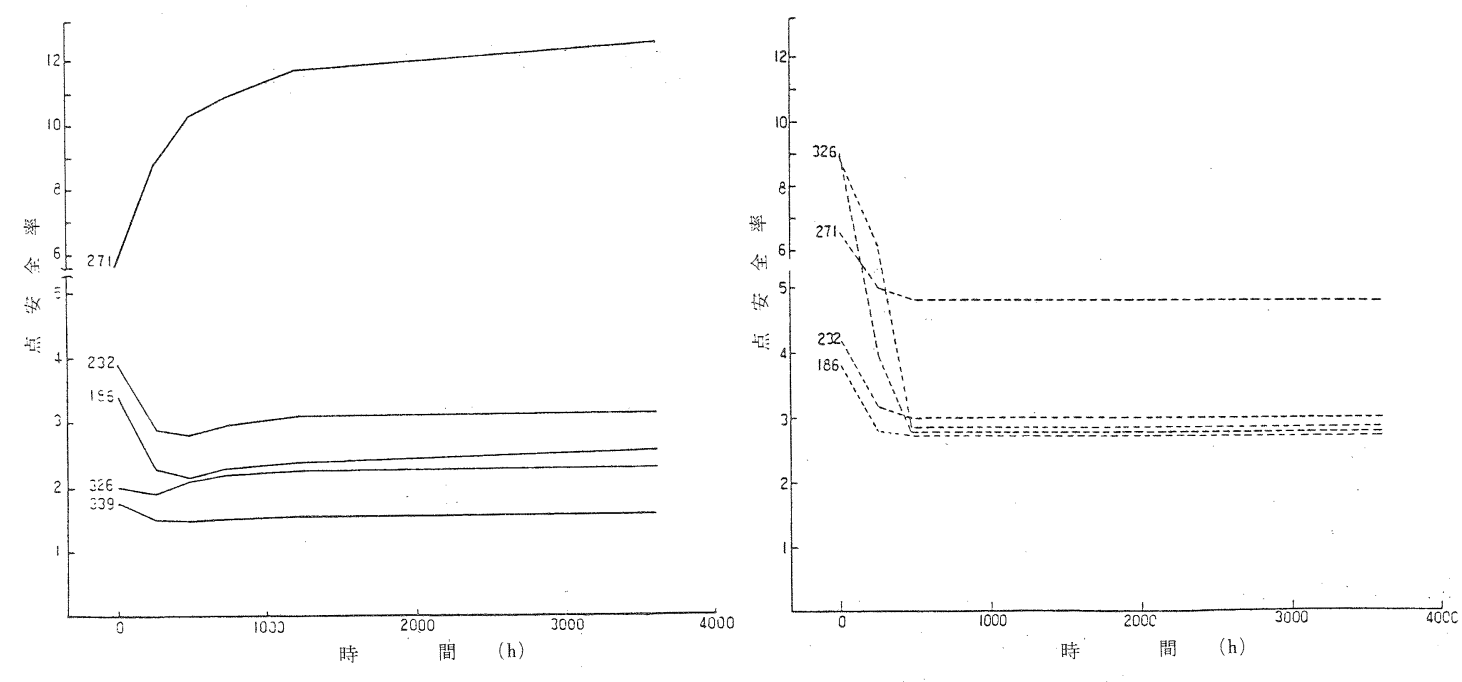

図-8 点安全率の経時変化

貯水池水位の変化は間隙水圧の非定常分布を考察の対 象とするため, 実情とは多少相違するが初期水位 $65 \mathrm{~m}$ 240 時間後 $45 \mathrm{~m}$ に低下し，480時間後 $30 \mathrm{~m}$ に低下しその後 一定値を保つものとした。簡単のため透水係数は $1 \times$ $10^{-3} \mathrm{~cm} / \mathrm{s}$ ，間吵率は 0.3 , 比貯留係数は $0.003 \mathrm{~m}^{-1}$ とした。 地山応力の解析は時刻 $0 \mathrm{~h}, 240 \mathrm{~h}, 480 \mathrm{~h}, 720 \mathrm{~h}, 1,200 \mathrm{~h}$, $3,600 \mathrm{~h}$ 各時刻において実施した。

ヤング率は $1.5 \times 10^{5} \mathrm{tf} / \mathrm{m}^{2}$, ポアソン比は0.3, 粘着力は $20 \mathrm{tf} / \mathrm{m}^{2}$, せん断抵抗角は 30 度とした。なお地山の単位体 積重量は間隙水の有無によって変化するが，ここでは 2 $\mathrm{tf} / \mathrm{m}^{3}$ とした。図一 3 に解析結果の一例として時刻720hに おける間隙水压の分布を示す。図一 4 は同時刻における 地山の主応力の大きさと方向を示す。図一 5 は同時刻に おける最大主応力の分布状況である。図ー6 は同時刻で
の各要素における点安全率を示している。また図ー7の 実線は同時刻に地山に発生した変位を示している。ただ し点線は水位 $0 \mathrm{~m}$ で間吵水压も存在しない時の位置を示 している。

図一 8 は間吵水圧を考慮した場合と, 無視した場合の 点安全率の比較であり, 図中の数字は要素番号である。 この図から明らかなように間隙水圧を考慮すると安全率 が大きく低下する所と上昇する所があるが，一般に低下 する方が多い。ここで求めた点安全率と全体安全率がど のように関係するかは今後の問題であるが, 両者は常識 的には同一傾向で変化すると考えられるので, 上記結果 から応力解析において間吵水圧を考慮することが安全確 保を確実とするため必要であることは言うまでもない。 


\section{5 .あとがき}

地山中に分布する応力は間隙水圧に影響されて変化す る。したがって弾性力学理論による応力解析においても 間隙水圧の考慮が必要である。しかし従来市販されてい る普通の有限要素応力解析プログラムでは間隙水圧を考 慮することができなかった。そこで筆者らは手持ちのプ ログラムを改良して応力解析を行った。なお間隙水圧と 応力の関係を総合的に把握するため, 簡単なモデルにつ いて理論式による解析を行った。そして土留め, 擁壁等 の設計に於いて，間隙水圧を考慮した応力解析が必要な ことを明らかにした。さらに貯水池両岸の貯水水位の変 化による応力変化について電子計算機による解析を行つ た。その結果この例では貯水水位低下による両岸の安全 率について, 点安全率の変化から判断すると, 間隙水圧 を考慮した解析のほうが一般に小さくなると推定された。 すなわち傾斜地形の安定評価についても間隙水圧を考慮 した解析の必要性が明らかになった。

\section{付 録}

普通応力・ひずみ関係式としてフックの式尔が用いら れるが，この式では間隙水圧の影響を考慮することがで きない。このためビオにより間隙水圧を考慮した応力・ ひずみ関係式が与えられた。ここではそれを簡略化して 紹介する。

地山中に図－9のような直交座標を設定し，X，Y， Z方向にそれぞれ単位長さを有する立方体を考える。こ の立方体中に存在する土, 砂その他の固形物体をモデル 化して球と考えると図一10のようになる。さらに球と球 の間には排水可能な間隙水圧が存在し, 球に間隙水圧 $p$ を与えているものとする。さて前記立方体の各表面には 球の切断面と間隙の切断面が現れているが, これら各表 面に間隙水圧 $p$ (正值) に等しい圧縮応力 $\sigma_{p}$ (負值) が加 えられていれば，球の切断面にも圧力 $p$ が作用したと同 等になる。すなわち立方体中の全球にたいし等方圧力 $p$ が作用したことになるので，立方体に生ずる体積ひずみ $\varepsilon_{p}$ は

$$
\varepsilon_{p}=\sigma_{p} / K_{0}=-p / K_{0}
$$

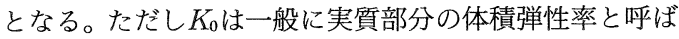
れている物性値である。

なお地山が等方性の場合 $\mathrm{X}, \mathrm{Y}, \mathrm{Z}$ 方向のひずみ $\varepsilon_{p x}$, $\varepsilon_{p y}, \varepsilon_{p z}$ は

$$
\varepsilon_{p x}=\varepsilon_{p y}=\varepsilon_{p z}=\frac{1}{3} \varepsilon_{p}=\frac{-p}{3 K_{0}}
$$

となる。

次に図ー 11 に示すよう $\mathrm{X}, \mathrm{Y}, \mathrm{Z}$ 方向にそれぞれ圧縮 応力 $\sigma_{x}, \sigma_{y}, \sigma_{z}$ が作用する場合は, 図一 12 のように応力 $\sigma_{x}$

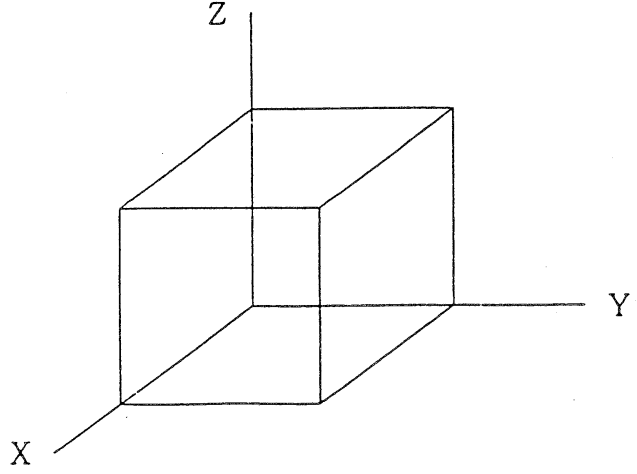

図ー9地山中に設定した座標系

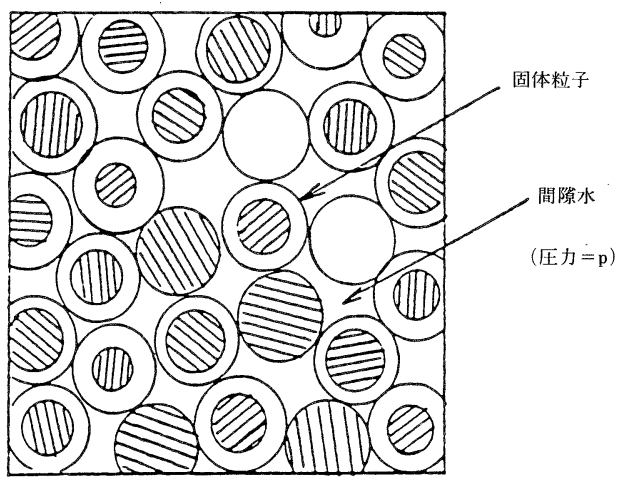

図ー10 地山のモデル

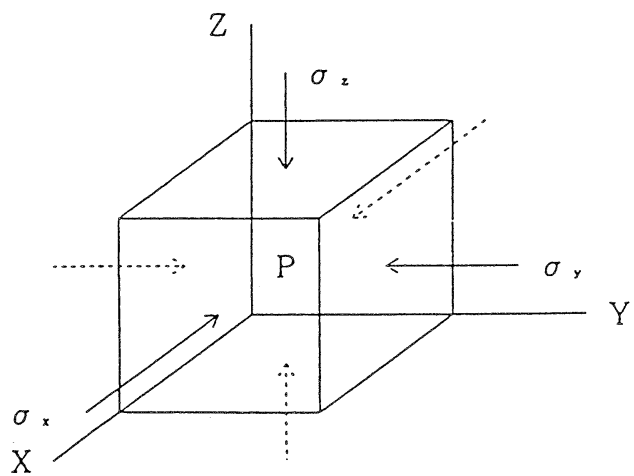

図-11 応力と間隙水圧の同時作用 を $\sigma_{p}(=-p)$ と $\sigma_{x}-\sigma_{p}$ (テルツァギィーの有効応力）に分 け， $\sigma_{y}, \sigma_{z}$ も同様に分けて，ひずみを求める。第 1 の負荷 によって発生するX方向のひずみ $\varepsilon_{p x} は(14)$ 式で定まり, 第 2 の負荷に対する $\varepsilon_{0 x}$ は間隙水圧がないのでフックの法 則が適用でき, 球の集合体に対するヤング率を $E$, ポアソ ン比をレとすると

$$
\begin{aligned}
\varepsilon_{o x} & \left.=\frac{1}{E}\left\{\sigma_{x}-\sigma_{p}\right)-\nu\left(\sigma_{y}-\sigma_{p}\right)-\nu\left(\sigma_{z}-\sigma_{p}\right)\right\} \\
& =\frac{1}{E}\left\{\sigma_{x}-\nu\left(\sigma_{y}+\sigma_{z}\right)\right\}+(1-2 \nu) p \cdots \cdots \cdots
\end{aligned}
$$

となる。したがって第 1 , 第 2 の負荷によってX方向に 


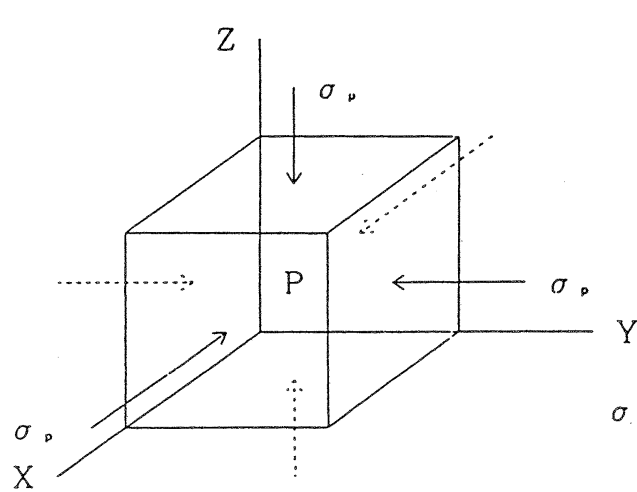

第 1 負荷

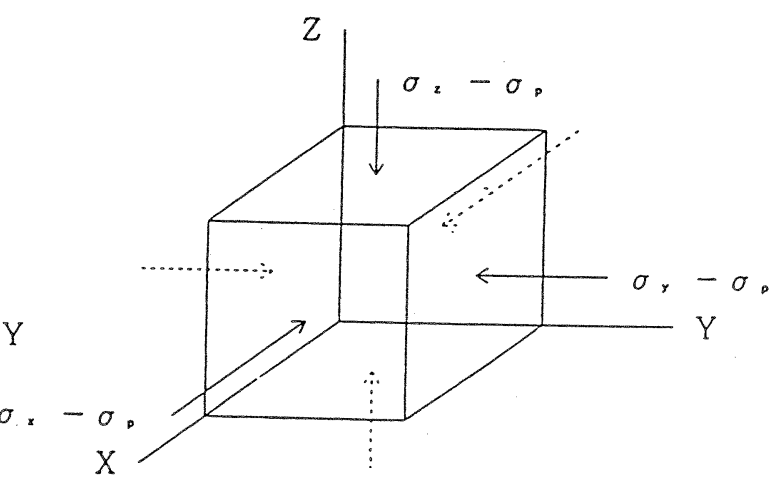

第 2 急荷

図-12 応力の分割負荷

表一1 $p=1 \mathrm{kgf} / \mathrm{cm}^{2}\left\{98 \mathrm{kN} / \mathrm{m}^{2}\right\}$ における各種物質の圧縮性

\begin{tabular}{|c|c|c|c|c|c|c|c|}
\hline & \multirow{2}{*}{\multicolumn{2}{|c|}{ 物 }} & \multirow{2}{*}{ 質 } & \multicolumn{4}{|c|}{ 压縮性 $\mathrm{cm}^{2} / \mathrm{kgf}\left\{\mathrm{m}^{2} / \mathrm{kN}\right\}$} \\
\hline & & & & \multicolumn{2}{|c|}{$m_{v}$} & \multicolumn{2}{|c|}{$m_{s}$} \\
\hline 石 & 英 & 質 & 砂 & $5.8 \times 10^{-6}$ & $\left\{5.92 \times 10^{-8}\right\}$ & $2.7 \times 10^{-6}$ & $\left\{2.76 \times 10^{-8}\right\}$ \\
\hline 花 & & 崗 & 岩 & $7.5 \times 10^{-6}$ & $\left\{7.65 \times 10^{-8}\right\}$ & $1.9 \times 10^{-6}$ & $\left\{1.94 \times 10^{-8}\right\}$ \\
\hline 大 & & 理 & 石 & $17.5 \times 10^{-6}$ & $\left\{17.86 \times 10^{-8}\right\}$ & $1.4 \times 10^{-6}$ & $\left\{1.43 \times 10^{-8}\right\}$ \\
\hline コ & ン & クリ & - & $20.0 \times 10^{-6}$ & $\left\{20.41 \times 10^{-8}\right\}$ & $2.5 \times 10^{-6}$ & $\left\{2.55 \times 10^{-8}\right\}$ \\
\hline 密 & & な & 砂 & $1,800.0 \times 10^{-6}$ & $\left\{1,840.0 \times 10^{-8}\right\}$ & $2.7 \times 10^{-6}$ & $\left\{2.76 \times 10^{-8}\right\}$ \\
\hline 粗 & & w & 砂 & $9,000.0 \times 10^{-6}$ & $\left\{9,180.0 \times 10^{-8}\right\}$ & $2.7 \times 10^{-6}$ & $\left\{2.76 \times 10^{-8}\right\}$ \\
\hline \multicolumn{4}{|c|}{ 過圧密粘土 (洪積粘土) } & $7,500.0 \times 10^{-6}$ & $\left\{7,650.0 \times 10^{-8}\right\}$ & $2.0 \times 10^{-6}$ & $\left\{2.04 \times 10^{-8}\right\}$ \\
\hline \multicolumn{4}{|c|}{ 正規圧密粘土 (沖積粘土) } & \multicolumn{2}{|c|}{$60,000.0 \times 10^{-6} \quad\left\{61,200.0 \times 10^{-8}\right\}$} & $2.0 \times 10^{-6}$ & $\left\{2.04 \times 10^{-8}\right\}$ \\
\hline \multicolumn{4}{|c|}{ 水 } & $48.0 \times 10^{-6}$ & $\left\{48.96 \times 10^{-8}\right\}$ & \multicolumn{2}{|c|}{$48.0 \times 10^{-6}\left\{48.96 \times 10^{-8}\right\}$} \\
\hline
\end{tabular}

$m_{v}$ ：全体の圧縮性, $m_{s}$ ：実質部の圧縮性

発生するひずみ $\varepsilon_{x}$ は $\varepsilon_{p x}$ と $\varepsilon_{o x}$ を加えて

$$
\begin{aligned}
\varepsilon_{x} & =\varepsilon_{p x}+\varepsilon_{o x} \\
& =\frac{1}{E}\left\{\sigma_{x}-\nu\left(\sigma_{y}+\sigma_{z}\right)\right\}+\frac{p}{3 K}-\frac{p}{3 K_{0}} \\
& =\frac{1}{E}\left\{\sigma_{x}-\nu\left(\sigma_{y}+\sigma_{z}\right)\right\}+\frac{p}{3 K}\left(1-\frac{K}{K_{0}}\right)
\end{aligned}
$$

となる。ただし

$$
K=\frac{E}{3(1-2 \nu)}
$$

は球の集合体に対する体積弾性率である。

上記と同様に $Y$ 方向のひずみ $\varepsilon_{y}, Z$ 方向のひずみ $\varepsilon_{z}$ を 求めると

$$
\begin{aligned}
& \varepsilon_{y}=\frac{1}{E}\left\{\sigma_{y}-\nu\left(\sigma_{z}+\sigma_{x}\right)\right\}+\frac{p}{3 K}\left(1-\frac{K}{K_{0}}\right) \\
& \varepsilon_{z}=\frac{1}{E}\left\{\sigma_{z}-\nu\left(\sigma_{x}+\sigma_{y}\right)\right\}+\frac{p}{3 K}\left(1-\frac{K}{K_{0}}\right)
\end{aligned}
$$

となる。当然なことであるが $p=0$ の場合(16)，(17)，(18)式は フックの応力・ひずみ関係式と完全に一致する。

なお間隙水圧はその圧力の大小によらずせん断変形に 抵抗しないので，せん断ひずみはせん断応力のみに関係 し間隙水圧に無関係に

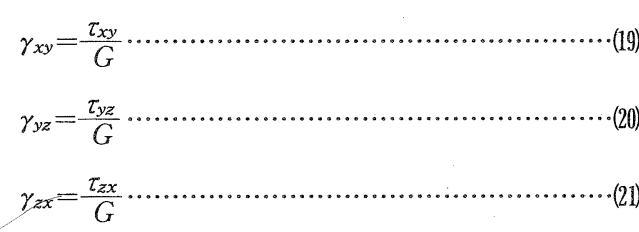

となる。ただし $G$ は球の集合体に対するせん断弾性率で ある。

以上が間隙水圧を考慮したときの応力ーひずみ関係で あるが(16)，(17)，(18)式を応力について解きひずみで応力を 示す式を求めると

$$
\begin{aligned}
\sigma_{x}= & \frac{E}{(1+\nu)(1-2 \nu)}\left\{(1-\nu) \varepsilon_{x}\right. \\
& \left.+\nu\left(\varepsilon_{y}+\varepsilon_{z}\right)\right\}-\beta p \cdots \ldots \ldots . . \\
\sigma_{y}= & \frac{E}{(1+\nu)(1-2 \nu)}\left\{(1-\nu) \varepsilon_{y}\right. \\
& \left.+\nu\left(\varepsilon_{z}+\varepsilon_{x}\right)\right\}-\beta p \cdots \ldots \ldots . . \\
\sigma_{z}= & \frac{E}{(1+\nu)(1-2 \nu)}\left\{(1-\nu) \varepsilon_{z}\right. \\
& \left.+\nu\left(\varepsilon_{x}+\varepsilon_{y}\right)\right\}-\beta p \cdots \ldots \ldots .
\end{aligned}
$$

となる。ただし

$$
\beta=1-\frac{K}{K_{0}}
$$

である。 
表- 1 は土質工学ハンドブック5から引用した土，砂， 岩石等の実質のみの圧縮性 $m_{s}$, 全体の圧縮性 $m_{v}$ である。 $m_{s}=1 / K_{0}, m_{v}=1 / K$ だか一般に土, 砂などでは $K$ に対 して $K_{0}$ が十分大きくなり $\beta=1$ とすることができる。

最後に(16)，(17)，(18)式の適用限界について考察する。こ れら各式には球の集合体のヤング率が用いられているが, 球の集合体の場合このヤング率は圧縮応力に対するもの で引っ張り応力に適用することができない。したがっ て $\sigma_{x}-\sigma_{p}, \sigma_{y}-\sigma_{p}, \sigma_{z}-\sigma_{p}$ の一つでも正值となる場合, これら各式および(22)，(23)，(24)式は用いることはできない。

\section{参考文献}

1) Biot, M. A.: General Theory of Three-dimensional Consoridation Journ. Appl.Phys. 12.155.1941

2) 三好俊郎他： 演習有限要素法, サイエンス社, 1986

3) 富士通エフ, アイ, ピー：地盤変形解析プログラム解説 書, 1987

4 ) 渥美光： 機械工学体系(8), 固体力学概論, コロナ社, 1978

5 ）土質工学会：土質工学ハンドブック，1982

(原稿受理日 平成 3 年 1 月 28 日)

\section{新刊紹介：}

「コンピュータ編集による日本地質図

$$
(1: 2,000,000)\lrcorner
$$

山田直利・斉藤英二・村田泰章著

(地質調査所，1990）

日本では，国土地理院によって全域の 5 万分の 1 をは じめとする各種の地形図が発行され，また地質調査所に よって同じく 5 万分の 1 地質図など多くの地質図が刊行 されており，地すべりの研究にとって，最も基本的な地 形・地質情報が容易に入手できる恵まれた環境にある。 これらの情報は 1 種のデータベースであるもののアナロ グ情報であり，現在のようにコンピュータが普及してい る時代からみれば，これらのデジタル化が望ましいこと である。現在，デジタル地形情報としては国土地理院の 国土数值情報が知られているが，地質情報はデジタル化 しにくい情報もあって今でも多色刷りの地質図で我慢し ているところである。

地質調查所では数年前から本格的に地質図のデジタル 化に取り組み，いくつかの地質データベース・システム を構築する作業を進めてきた。その成果の一環として今 回この 200 万分の 1 日本地質図を作成した。

この日本地質図は，工業技術院特別研究「地質デー夕
ベースの開発と利用に関するパイロット研究」（19851989）の「地質図データベースの研究」の一部として作 成された。原図は，地質調査所による日本地質アトラス (1982)の一つとして発行された100万分の 1 の地質図で ある。この地質図のデジタル数值ファイルはサンシャイ ン計画の地熱情報データベース・システム（SIGMA）に 基づくもので，地形基図は国土地理院の国土数值情報と 海上保安庁の水深データファイルを用いてある。これら に基づいてコンピュータマッピングの手法で, (1)地質数 值ファイルの更新，(2)地形図の更新，(3)地質図の編集， (4)印刷が実施されて作成された。この新手法によれば， 従来の手法による地質図とともにデジタル地質図のファ イルが同時に作成されることにより，最も労力のかかる 地質区分の変更とそれに基づく製図と印刷（とくに多色 刷り）の工程が著しく節約できる。それとともに，地質 図がデジタルファイルとして供給されることも可能とな り,地質図の利用方法も大きく変わり, 我々にとってもっ となじみ易いものになるであろうと考えられる。この地 質図はその第 1 歩をなすものであり，今後このような努 力が重ねられることを期待してやまない。

本地質図は最新の地質情報に基づいており，かつ全紙 大の紙 1 枚に収まっているので, 日本全土の地質図とし て丁度手ごろなものとして薦める次第である。

(文責：藤田 崇) 